Impact of Reinsurance on Performance of Nepalese Insurance Companies

\title{
Impact of Reinsurance on Performance of Nepalese Insurance Companies
}

\author{
Rajendra Maharjan * \\ Midwestern University, Birendrangar, Shurkhet \\ rajendra.maharjan707@gmail.com
}

\begin{abstract}
Reinsurance is considered as backbone of the insurance industry in developed and developing countries as it indirectly injects capital and Nepalese insurance companies are no exception. Thus, this study is aims to find out whether the use of reinsurance arrangement lead to positive effect or not? Three portfolios have been formed life, nonlife and industry. The study used 11 years unbalanced cross sectional secondary data from 2007/08 to 2017/18. The sample of the study consists of seven from life and nine from nonlife with 138 firm years' observations. The dependent variable performance is measured by profitability (ROA and ROE) and solvency while reinsurance ceded as explanatory variable. Capital employed and size of the firm are considered as control variables. The study employed descriptive cum causal comparative research design. Regression analysis has been performed to see the effect of reinsurance on firm performance.

The result depicts that reinsurance has a positive and significant impact on performance of insurance companies. This finding indicates that reinsurance improves the cost efficiency of primary insurers. Further, reinsurance is a complement for capital in order to enhance solvency while negative relation indicating solvency of the insurers increases with the level of used reinsurance, to the extent that reinsurance and capital can be substitutes of each other. Thus, this study concludes that primary insurers can benefit from reinsurance as its relief on capital, diversify risk and in turn helps to earn profitability by sharing the risk with reinsurers.
\end{abstract}

Keywords: Reinsurance, Profitability, Solvency, Capital, Premium

\section{Introduction}

Reinsurance is one of the major pillars of insurance industry providing the financial back up by taking the excess risk beyond the company capacity. In other words, Insurance companies purchase reinsurance to protect themselves against the risks of losses above certain thresholds. According to Outreville (2002), reinsurance is a mechanism transferring the liability of the primary insurer to the other company known as reinsurance company. The business placed with a reinsurer is called a cession of an insurance company. According to Group of Thirty (2006) reinsurance helps to diversify risk, reduce, volatility of income, increase underwriting capacity, inject indirect capital, get technical advice and help to reduce threaten of financial stability. Despite having some of the advantage's reinsurance introduces several risks that

* Currently working in Beema Samiti (Insurance Regulatory Authority of Nepal) as an Assistant Director.

NJMSR V. 3 Issue 2 (2019) 139 
could threaten financial stability such as increase credit risk, difficult to maintain account due to different accounting year, increase cost, reduce profitability.

UNCTAD (2007) highlight the key role in fostering commercial and infrastructural businesses. It promotes financial and social stability; mobilizes and channels savings; supports trade, commerce and entrepreneurial activity and improves the quality of the lives of individuals and the overall wellbeing in a country. The proper functioning of a financial system is essential in facilitating economic activity of any country. It plays the crucial part in the economic development of the country. Falling of financial system can severely affect in the economy. Insurance as an intermediary help in channelizing the fund from savers to the users for productive sector. Insurance is a mechanism to transfer the risk of human life and property. Furthermore, insurers, can also contribute to efficient allocation of funds through their investments in driving the economic to the prosperity. (Leyvelda, et. al., 2011).

Sharma (2018) defines reinsurance is an insurance of insurance and is one of the important tools of risk management and is a worldwide practice both by developed and developing country. There is no universally accepted and derived formula to determine the retention level of the primary insurer; however, paid up capital, reserved fund, equity, reinsurance regulation of the country and risk profile are some of the major factors that should be considered while determining the retention level of the company.

The empirical evidence suggests that the purchase of reinsurance introduces substantial changes to several characteristics of insurers, besides their risk profile. Previous several empirical studies had focused and analyzed the purchase of reinsurance from the perspective of risk management, focusing on reinsurance as a tool for risk mitigation. Among others, see for example Doherty \& Berger et al. (1992), Garven \& Lamm-Tennant (2003), Cole \& McCullough (2006), Powell \& Sommer (2007), Mankai \& Belgacem (2016), and Surminski (2018). Recent study by Altuntas et al. (2018) provides an interesting of overview on the usage of reinsurance across countries, assessing the importance of country-level and firmlevel factors in explaining the purchase of reinsurance.

This article analyzes the effect of reinsurance on solvency and profitability of Nepalese insurers. The interaction between reinsurance and solvency is discussed by Nissim (2010), and Kuschel et al. (2011). In respect to the link with performance, for example Cole and McCullough (2006), and Lee \& Lee (2012) showed that the reinsurance is important and has a positive and statistically significant impact on the profitability. In contrast, Choi (2010) \& Choi \& Elyasiani (2011) document that reinsurance reduces growth and efficiency.

The study contributions to the existing literature. The majority of the previous articles considers firm solvency and profitability in a separate way, whereas this study considers the two aspects jointly. This allows making conclusions on whether reinsurance affects one aspect more strongly than the others. De Haan \& Kakes (2010) used data from about 350 Dutch insurers during the period 1995-2005, with 700 firm year observations, Gaganis (2013), have a sample made by 4,321 observations for life and non-life insurers during the period 20052007, while this study uses only 16 firm with 138 firm year observation only. Even though knowing the relatively huge sample could improve the robustness of the insights that the study could draw out of the empirical outcomes but this study couldn't able to incorporate all the firm is one of the limitations of the study. The next limitation the study used unbalance panel 
Impact of Reinsurance on Performance of Nepalese Insurance Companies

data filled with average value in missing place. Finally, the study points out important effects arising from reinsurance that will deserve additional analyses and theoretical thoughts for future research.

The history of the insurance industry is not long. The first general insurance company Nepal insurance and transport company was established as a subsidiary company of Nepal bank in 1947 now known a Nepal insurance company. After wards, Rastirya Beema Company was established in the year 1968 under Rastriya Beema Sansthan Act, 1968. In early 80's one life insurance company called national life insurance was established. With the liberalization policy of the Nepal government insurance companies were flourish during $90 \mathrm{~s}$ in alarming rate and in 20 s totaling 25 insurance company. Recently two years back 13 insurance companies were added now total 40 insurance company that constitutes 19 life, 20 nonlife and 1 reinsurance company (Annual Report, 2017/18).

The main objective of this article is to examine the impact of reinsurance on performance of the insurance companies. The article proceeds as follows. Section 2 research methodology and also introduces the sample and defines the main variables for the analysis. Section 3 formulates hypotheses that relate insurers' solvency followed by testing of these hypotheses on section 4 result and discussion. The last section of the study i.e. section 5 concludes the study with implication of the study.

\section{Research Methodology}

This study employed descriptive cum causal comparative research design to see the cause effect of independent variables on dependent. Three portfolios have been formed to see the effect of reinsurance practices as life insurance company, nonlife insurance company and insurance industry.

\subsection{Sample and data}

The study area of the study is the financial sector of Nepal with reference to the insurance industry in particular. The population of the study is all insurance company operating in Nepal. The study period for the study is 10 year starting from 2007/08 to 2017/18. Out of 19 life insurance company only 7 are selected as 10 of them were newly established, two companies Metlife (ALICO) and Rastriya Beema Sansthan does not avail the data. Similarly, in case of nonlife out of 20 nonlife, 9 were selected as 3 of them were newly established and remaining firms were well represented by the sample firm. The study used unbalanced crosssectional data with 66 firm year observation from life, 72 from life resulting 138 firm year observation in aggregate.

The study used the ordinary least square (OLS) model tested by Bressan (2018) after confronting multi-collinearity test and heteroscedasticity for every firm $i$ at time $t$, to analyze the $5 \mathrm{f}$ effect of reinsurance on firm-specific characteristics: The model has been tested for three portfolio life, nonlife and industry.

$$
\text { Insurer characteristics }{ }_{i, t}=\alpha+\beta * \text { REINS_USED }_{-} \theta * \text { Control }_{i, t}+v_{, i}+\tau_{, t}+\varepsilon_{i, t}
$$

Where, the insurer-specific characteristics that the consider are profitability as represented by ROA and ROE and solvency. $\theta$ is the vector of coefficients for the control variables of the 
regressions. In all models control for size effects with the inclusion of the logarithm of total assets (LOG A SSETS). The regressions for the profitability and solvency indicators control for capital levels. The analysis of the model has been carried on by the model tested by Bressan, S. (2018) using cross-sectional unbalanced data. $\varepsilon_{i, t}$ is an error term. Standard errors are clustered at the firm level to control for within firm level.

\subsection{Variables and its measurement}

The study uses profitability and solvency as a dependent variable while reinsurance as independent variable. Capital 1, Capital 2 and assets are used as a control variable. The variable Reins_USED is an indicator for the reinsurance used by the company, as it normalizes the reinsurers' share of technical provisions over total assets. Technical provisions are the amounts set aside to fulfill obligations to policyholders. Setting technical provisions implies the estimation of loss reserves, and the attempt to give reliable insights into future claims emergence by means of different actuarial technique. The variable CAPITAL 1 divides the sum of equity capital and surplus by total assets. CAPITAL 2 captures the solvency of the firm. Insurers with a high level of CAPITAL 2 would be relatively solvent, as they hold sufficient resources to fully cover their obligations. For robustness, we test also the ratio of equity capital over total earned premiums.

The widely used approach to measure the profitability is return on assets (ROA) and return on equity (ROE). The variable ROA is measure by taking the ratio of net income to total assets. In addition, we divide net income to total equity for the measurement of ROE. The detail is presented in table 1 below. Table 1 shows the variables and their measurement that have been used in the study.

Table 1

Variables and it's Measurement

\begin{tabular}{llll}
\hline $\begin{array}{l}\text { Dependent } \\
\text { Variables }\end{array}$ & Profitability & $\begin{array}{l}\text { Return on Assets (ROA) } \\
\text { Return on Equity (ROE) }\end{array}$ & $\begin{array}{l}\text { Net Income to Total Assets } \\
\text { Net Income to Total Equity }\end{array}$ \\
& Solvency & Solvency & $\begin{array}{l}\text { Net Assets to Higher of Paid up Capital } \\
\text { or, 20 Percent of Net Premium or } \\
\text { Average Claim Outstanding over last } 3\end{array}$ \\
& & & $\begin{array}{l}\text { year } \\
\text { Independent }\end{array}$ \\
Variables & $\begin{array}{l}\text { Reinsurance } \\
\text { Ceded }\end{array}$ & REINS_USED & $\begin{array}{l}\text { Net reinsurance premium ceded to Total } \\
\text { Assets }\end{array}$ \\
Control & Capital & CAPITAL1 & Ratio of Net worth to Total Assets \\
Variables & Employed & CAPITAL2 & Ratio of Net worth to Earned Premium \\
& Total Assets & Log_TA & Natural Logarithm of Total Assets \\
\hline
\end{tabular}

Source: Annual Reports of sample Companies

\section{Working Hypothesis}

In this section two working hypothesis are formulated that relate the insurer solvency and profitability to the reinsurance utilized by the same firm. Beginning with first hypothesis; reinsurance and profitability. The literature brought two contrasting view; the use of reinsurance carries substantial cost, to the point that it leads to higher prices and/or lower profits in one 
Impact of Reinsurance on Performance of Nepalese Insurance Companies

hand, on the other hand reinsurance provides financial backup, risk diversification, increase underwriting service of the primary insurer (Group thirty, 2007). Choi (2010), Shilu (2011) documented that excess use of reinsurance reduces growth and reduces the efficiency and profitability of the insurer. Lee \& Lee (2012) suggest primary insurer could perform better if insurer don't cede to the reinsurer at the point that the insurer can retain to the maximum. But in reality, it is very interesting to identify the point where the firm could retain high due to the unpredictable risk of different portfolios. In contrast, Choi \& Weiss (2005) study reveal that there is a link between reinsurance and profitability, however, reinsurance is not statistically significant. The other empirical findings by MuCullough (2006), Lee \& Lee (2012) suggest that there is a positive and significant impact of reinsurance on profitability. Based on the above discussion the study formulates the following hypothesis.

$H_{0}$ : There is no significant impact of reinsurance on profitability of the insurance company

$H_{1}$ : There is significant impact of reinsurance on profitability of the insurance company

$H_{12}$ : If reinsurance is expensive to the extent that it has an impact on cadent profitability; then, negative effect of reinsurance on profitability

$H_{11}$ : If reinsurance improves cost efficiency; then, there is a positive impact of reinsurance on the profitability of the primary insurers.

The second aspect the study consider is solvency. The literature discusses whether the usage of reinsurance carries substantial effect on solvency of the firm. The purpose of reinsurance is primarily to transfer risk from cedant to reinsurer, therefore the ability of the cedant to remain solvent should increase after sharing part of its risk with the reinsurer due to the increasing credit risk (Adam et al., 2008). Moreover, high retention by Nepalese company is also not possible due to low capital, high risk due to earthquake prone zone and frequent other natural calamities. In general, capital ratios should serve as measures for the assessment of capital adequacy. However, there is no clear evidence whether the usage of reinsurance would bring changes to capital levels of insurers.

The correlation between reinsurance and solvency is negative if capital and reinsurance act as substitutes for enhancing solvency, i.e. reinsurance allows achieving a given level of insolvency risk with lower capitalization (Berger et al., 1992; Garven \& Lamm-Tennant, 2003; Powell \& Sommer, 2007; De Haan \& Kakes, 2010). In contrast, the correlation is positive if reinsurance reduces the strain on regulatory capital both by reducing exposure and increasing surplus Nissim (2010). For example, Kuschel et al. (2011) suggests that different reinsurance programs end up to increase the solvency of European insurers, as supported by trends in the regulatory capital requirements. To summarize, we develop the following hypothesis.

$H_{0}$ : There is no significant impact of reinsurance on solvency of the insurance company

$H_{1}$ : There is significant impact of reinsurance on solvency of the insurance company

$H_{01}$ : If the solvency of insurers increases with the level of used reinsurance to the extent that reinsurance and capital can be seen as substitutes then; a negative relation can be observing effect of REINS USED on Solvency.

$H_{02}$ : If reinsurance is a complement for capital in order to enhance solvency, the effect of REINS USED on solvency should be positive

NJMSR V. 3 Issue 2(2019) 143 


\section{Results and Discussion}

\subsection{Descriptive Statistics}

In order to dig more deeply into the composition of the sample, Table 2 reports statistics by segment of insurance. This decomposition reveals interesting differences. For example, nonlife insurers utilize reinsurance in a larger extent than the life insurers. This evidence confirms the findings of Baur and Breutel-O'Donoghue (2004), documented the usage of reinsurance is generally in higher by nonlife insurance company. Similar finding is observed by Nissim (2010) emphasizing the reinsurance is used extensively in property and casualty insurance, while it is less common in life. This is primarily due to the fact that reinsurance exhibits significant limitations as a risk transfer mechanism in respect to longevity risk. This argument is supported in Nepalese context as well. Table 3 confirm that mean reinsurance used by life insurers is close to 2.6 percent while in nonlife insurers counts 67.8 percent, whereas overall sample represent 73.1 percent. Profitability as measured by ROA averaging 7.9 percent, while 14.3 percent in non-life insurers. Similarly, ROE for life and non-life insures is 20.1 percent and 17.2 percent producing 18.6 for the industry. Both the life and non-life insurance company were enabling in maintaining the required solvency margin of 1.5 . The results are presented in table below.

\section{Table 2}

Descriptive Statistics

\begin{tabular}{lllllclc}
\hline & & \multicolumn{2}{c}{ Life } & \multicolumn{2}{c}{ Nonlife } & \multicolumn{2}{c}{ Industry } \\
\hline & \multicolumn{1}{c}{ Unit } & Mean & Std. Dev & Mean & $\begin{array}{l}\text { Std. } \\
\text { Dev }\end{array}$ & Mean & Std. Dev \\
\hline ROA & Percent & 0.079 & 0.422 & 0.143 & 1.349 & 0.125 & 1.067 \\
ROE & Percent & 0.201 & 0.475 & 0.172 & 0.113 & 0.186 & 0.338 \\
Solvency & Times & 2.611 & 0.934 & 2.518 & 1.158 & 2.563 & 1.054 \\
REINS_USED & Percent & 0.026 & 0.053 & 0.6783 & 14.059 & 3.551 & 0.731 \\
CAPTAL1 & Percent & 0.250 & 0.222 & 0.4723 & 7.241 & 2.584 & 5.677 \\
CAPITAL2 & Percent & 0.922 & 1.197 & 0.5204 & 5.510 & 3.156 & 4.585 \\
TA & Rs. In Million & $9,963.436$ & $12,329.796$ & 338.708 & 544.590 & $4,942.404$ & $9,775.062$ \\
Log_TA & & 22.118 & 1.748 & 18.588 & 1.686 & 20.276 & 2.461 \\
N & & 66 & & 72 & & 138 & \\
\hline
\end{tabular}

Source: Annual Reports of sample Companies

Note: ROA is Net Income to Total Assets, ROE is the Net Income to Total Equity, Solvency is the Net Assets to Higher of Paid up Capital or, 20 Percent of Net Premium or Average Claim Outstanding over last 3 years, REINS_USED is the Net reinsurance premium ceded to Total Assets, CAPTAL1 is the Ratio of Net worth to Total Assets, CAPITAL2 is the Ratio of Net worth to Earned Premium and Log_TA is the natural logarithm of total assets. 
Impact of Reinsurance on Performance of Nepalese Insurance Companies

\subsection{Correlation Analysis}

The correlation coefficient measures the degree of association between variables under study. Table 3 displays results from the correlation coefficient between the dependent and independent variables of the insurance industry. Reinsurance and capital are positively related with ROA at 1 percent level of significant. In contrast, reinsurance and capital is negatively related with ROE but insignificant. Similar result has been observed reinsurance with solvency. Total asset is positively related with ROE and solvency and is negatively related with ROA, however the result producing no significant.

Table 3

Correlations Coefficient Matrix

\begin{tabular}{lcccccccc}
\hline & ROA & ROE & Solvency & $\begin{array}{c}\text { REINS_ } \\
\text { USED }\end{array}$ & $\begin{array}{c}\text { CAP- } \\
\text { TAL1 }\end{array}$ & $\begin{array}{c}\text { CAPI- } \\
\text { TAL2 }\end{array}$ & TA & Log_TA \\
\hline ROA & 1 & & & & & & & \\
ROE & -0.011 & 1 & & & & & & \\
Solvency & -0.048 & 0.097 & 1 & & & & & \\
REINS_USED & $0.827^{* *}$ & -0.025 & -0.043 & 1 & & & & \\
CAPTAL1 & $0.837^{* *}$ & -0.042 & 0.027 & $0.889^{* *}$ & 1 & & & \\
CAPITAL2 & $0.386^{* *}$ & -0.102 & 0.151 & $0.574^{* *}$ & $0.782^{* *}$ & 1 & & \\
TA & $-0.189^{*}$ & $0.213^{*}$ & 0.165 & $-0.167)$ & $-0.217^{*}$ & $-0.294^{* *}$ & 1 & \\
Log_TA & $-0.485^{*}$ & $0.215^{*}$ & 0.082 & $-0.468^{* *}$ & $-0.499^{* *}$ & $-0.539^{*}$ & $0.672^{* *}$ & 1 \\
\hline
\end{tabular}

Source: Annual Reports of sample Companies

Note: ROA is Net Income to Total Assets, ROE is the Net Income to Total Equity, Solvency is the Net Assets to Higher of Paid up Capital or, 20 Percent of Net Premium or Average Claim Outstanding over last 3 years, REINS_USED is the Net reinsurance premium ceded to Total Assets, CAPTAL1 is the Ratio of Net worth to Total Assets, CAPITAL2 is the Ratio of Net worth to Earned Premium and Log_TA is the natural logarithm of total assets. Under the null hypothesis. that the correlation coefficient is significant $x^{2} . * * * p<0.001, * * p<0.01$ $\& * p<0.05$

\subsection{Test of Multi-collinearity}

A certain degree of endo-geneity may affect the outcomes of the result. In order to dig more deeply in the issue of multi-collinearity, variance inflated factors (VIFs) for the equations of Table 4 where the impact of REINS USED is statistically significant. In particular, this would happen if the variable of interest REINS USED is strongly driven by the firm characteristics included in the right-hand side of the equations. VIFs detects multi-collinearity in the regression analysis (Tibshirani, 2017). Since, VIF is greater than one and tolerance level is less than one indicating there is no problem of multi-collinearity, therefore, no further suspect that multi-collinearity contaminates severely the quality of outcomes of the regression. 
Impact of Reinsurance on Performance of Nepalese Insurance Companies

Table 4

Variance Inflation factors (VIFs)

\begin{tabular}{lcccccc}
\hline & \multicolumn{2}{c}{ Life } & \multicolumn{2}{c}{ Nonlife } & \multicolumn{2}{c}{ Life and Nonlife } \\
\hline & Tolerance & VIF & Tolerance & VIF & Tolerance & VIF \\
\hline REINS_USED & 0.603 & 1.66 & 0.17 & 5.882 & 0.164 & 6.089 \\
CAPTAL1 & 0.187 & 5.345 & 0.112 & 0.892 & 0.098 & 10.175 \\
CAPITAL2 & 0.219 & 4.563 & 0.348 & 2.875 & 0.283 & 3.538 \\
Log_TA & 0.629 & 1.589 & 0.709 & 1.411 & 0.665 & 1.505 \\
\hline
\end{tabular}

Source: Annual Reports of Sample Companies

Note: REINS_USED is the Net reinsurance premium ceded to Total Assets, CAPTAL1 is the Ratio of Net worth to Total Assets, CAPITAL2 is the Ratio of Net worth to Earned Premium and Log TA is the natural logarithm of total assets

\subsection{Estimated OLS Regression of Reinsurance with Profitability}

The regression estimates of equation (1) has been tested for all three portfolios with dependent variable is profitability as measured by ROA and ROE. In light of Hypothesis 1 , in life portfolio, the result depicts that reinsurance is positive effect in profitability, however, result is significant with ROA only $(\mathrm{p}=0.035,<0.005)$. CAPITAL1 has a negative impact on profitability and is significant with ROA only with highly level of significance $(\mathrm{p}=0.000)$. CAPITAL2 is positive but not significant with profitability. Control variable asset is positive and has a high significant impact with ROA. This result demonstrates that alternative hypothesis is accepted i.e., reinsurance has a positive impact of reinsurance on the profitability of the primary insurers meaning reinsurance improves cost efficiency of the life insurance company in Nepal. Further, the model 1 is of best fit indicate by $F$ value $(F=55.71)$ with $\mathrm{R}^{2}=77.1$ percent, indicating explanatory variable explaining high percent variations in return on the profitability due to reinsurance in Nepalese insurance industry.

The regression estimates of equation (1) tested for nonlife insurance company with dependent variable profitability. In regard to first hypothesis, the result show that reinsurance is negative with ROA while positive with ROE but the result is not significant. This result indicating reinsurance has a no significant impact on Nepalese nonlife insurance company. Capitall has a positive and highly significant impact $(\mathrm{p}=0.000)$ with ROA while it not such significant with ROE. The next control variable CAPITAL2 has a negative relation with profitability. In regard to next control variable asset has negative and significant impact with ROA at 5 percent level of significant. While positive but insignificant impact on ROE. The overall model is best fit with $\mathrm{F}$ value 854.72 and $\mathrm{R}$ square 98 percent indicating very high explanatory power of intendent variable on profitability other than reinsurance factor.

The same OLS regression equation has been tested for industry the result effect in profitability. Reinsurance has negative and significant impact on profitability as measured by ROA ( $p=0.000$ ) while it was positive but insignificant with ROE. The control variables CAPITAL1, CAPITAL2 and asset has a positive and significant impact with ROA. The F value of the model is 464.27 which is highly fit with 93.1 percent explaining power of only asset is 
Impact of Reinsurance on Performance of Nepalese Insurance Companies

found to be positive and significant at 5 percent level $(p=0.045,<0.005)$ on profitability as measured by ROE in the insurance industry portfolio. From the analysis, the study concludes reinsurance is positively related with profitability in life insurer, this result is consistent with McCullough (2006), Grace (2007) and Lee \& Lee (2012). The negative and significant impact of reinsurance on profitability is observed in insurance industry indicating reinsurance reduces growth. This result is consistent with the finding from choli (2010) and Shiu (2011).

Table 5

Estimated OLS Regression of Reinsurance with Profitability

\begin{tabular}{lllllll}
\hline & \multicolumn{2}{c}{ Life } & \multicolumn{2}{c}{ Nonlife } & \multicolumn{2}{c}{ Industry } \\
\hline & \multicolumn{3}{c}{ Model 1 } & \multicolumn{2}{c}{ Model 2 } & \multicolumn{2}{c}{ Model 3 } \\
\hline $\begin{array}{l}\text { Independent } \\
\text { Variables }\end{array}$ & ROA & ROE & ROA & ROE & ROA & ROE \\
\hline REINS_USED & $0.673^{* *}$ & 0.826 & -0.007 & 0.003 & $-0.012^{*}$ & 0.002 \\
& $(5.116)$ & $(0.584)$ & $(1.830)$ & $(1.493)$ & $(2.098)$ & $(0.234)$ \\
CAPTAL1 & $-1.812^{* * *}$ & -0.538 & $0.275^{* * *}$ & 0.002 & $0.275^{* * *}$ & 0.005 \\
& $(6.941)$ & $(.882)$ & $(29.367)$ & $(0.564)$ & $(20.43)$ & $(0.340)$ \\
CAPITAL2 & 0.083 & 0.045 & $-0.189^{* * *}$ & -0.005 & $0.193^{* * *}$ & -0.005 \\
& $(1.867)$ & $(0.436)$ & $(26.918)$ & $(1.640)$ & $(19.663)$ & $(0.436)$ \\
& $-0.256^{* * *}$ & 0.045 & $-0.037^{*}$ & $0.049^{* * *}$ & $0.112^{* * *}$ & $0.034^{*}$ \\
Log_TA & $(14.140)$ & $(1.156)$ & $(2.308)$ & $(6.915)$ & $(9.639)$ & $(2.337)$ \\
Intercept & $6.083^{* * *}$ & -0.806 & $1.166^{* * *}$ & $-0.745^{* * *}$ & $2.630^{* * *}$ & -0.501 \\
& $(14.419)$ & $(1.155)$ & $(3.752)$ & $(5.417)$ & $(10.347)$ & $(1.657)$ \\
F-ratios & 55.705 & 1.242 & 854.72 & 14.687 & 464.272 & 1.927 \\
$\mathrm{R}^{2}$ & 0.771 & 0.015 & 0.98 & 0.435 & 0.931 & 0.026 \\
\hline
\end{tabular}

Source: Annual Reports of sample Companies

Note: The dependent variables are ROA and ROE which is measured by Net Income to Total Assets and Net Income to Equity. The independent variables. REINS_USED is the Net reinsurance premium ceded to Total Assets, CAPTAL1 is the Ratio of Net worth to Total Assets, CAPITAL2 is the Ratio of Net worth to Earned Premium and Log_TA is the natural logarithm of total assets. Figures in the parenthesis are heteroscedasticity corrected $t$-values. Under the null hypothesis. that the correlation coefficient is significant $x^{2} . * * * p<0.001, * * p<0.01$ $\&{ }^{*} p<0.05$.

\subsection{Estimated OLS Regression of Reinsurance with Solvency}

The OLS regression for all three portfolios life, nonlife and industry is demonstrated in table 6 with dependent variable Solvency. In light of Hypothesis 2, the result depicts that, there is positive effect of reinsurance in life and nonlife portfolio on solvency and is negatively related with industry, however, however, result is not significant $(p>0.005)$. CAPITAL1 and CAPITAL2 has a negative impact in all portfolio but significant with ROA only $(\mathrm{p}=0.004$, $<0.005$ ). Capital 2 is positive and significant at 5 percent in all portfolio indicating capital has positive impact on solvency. The other control variable asset has positive and significant impact on industry. 
Impact of Reinsurance on Performance of Nepalese Insurance Companies

Based on the above discussion, hypothesis 2 , reinsurance is a complement for capital in order to enhance solvency in life and nonlife portfolio whereas negative impact on insurance industry indicating solvency of insurers increases with the level of used reinsurance to the extent that reinsurance and capital can be seen as substitutes. From the analysis the study concludes there is no significant impact of reinsurance on solvency on Nepalese life insurer, nonlife and in industry.

Table 6

Estimated OLS Regression of Reinsurance on Solvency

\begin{tabular}{lccc}
\hline \multicolumn{1}{c}{ Independent Variables } & Life & Nonlife & Life and Nonlife \\
\hline REINS_USED & $1.111(0.417)$ & $0.006(0.247)$ & $0.007(0.349)$ \\
CAPTAL1 & $3.437^{* *}(2.995)$ & $0.020(0.376)$ & $0.021(0.424)$ \\
CAPITAL2 & $0.489^{* *}(2.493)$ & $0.094^{* *}(2.312)$ & $0.090^{* *}(2.488)$ \\
Log_TA & $0.067(0.842)$ & $0.121(1.296)$ & $0.087^{* *}(1.983)$ \\
Intercept & $4.469^{* *}(2.409)$ & $0.086(0.048)$ & $0.597(0.640)$ \\
F-ratios & 20752 & 2.363 & 2.72 \\
R2 & 0.097 & 0.071 & 0.048 \\
\hline
\end{tabular}

Source: Annual Reports of Sample Companies

Note: The dependent variable Solvency is measured by Net Assets to Higher of Paid up Capital or, 20 Percent of Net Premium or Average Claim Outstanding over last 3 years, the independent variables REINS_USED is the Net reinsurance premium ceded to Total Assets, CAPTAL1 is the Ratio of Net worth to Total Assets, CAPITAL2 is the Ratio of Net worth to Earned Premium and Log_TA is the natural logarithm of total assets. Figures in the parenthesis are heteroscedasticity corrected t-values. Under the null hypothesis. that the correlation coefficient is significant $x^{2} . * * p<0.001, * * p<0.01 \& * p<0.05$.

\section{Finding and Discussion}

Reinsurance is the backbone of the any developed and developing country. No doubt, it has been playing a one of the key roles in the fostering Nepalese insurance industry from the very beginning. The average reinsurance use is generally higher in nonlife than life. The mean value of capital, solvency and profitability is litter higher side in life than nonlife indicating Nepalese life insurance company need more capital, maintain higher solvency and earn relatively higher return than nonlife insurance company. The OLS regression result demonstrate that reinsurance has a positive and significant impact on profitability in life insurance indicating reinsurance improves cost efficiency of the primary life insurers while reinsurance has no significant role in nonlife insurance part. In contrast, reinsurance has a significant negative impact on industry meaning, reinsurance is expensive to the extent that it has an impact on cedent profitability.

Reinsurance is often taken as indirect capital inject to the insurance company as reissuance help back increase the underwriting capacity of the primary insurer. Thus, increase solvency indicating the firm is able to maintain strong financial status. The average solvency margin requirement is 1.5 times, below 1 is red while above 1.5 is grey zone. Reinsurance is positive but has no significant influence on solvency margin of both and nonlife insurance company, 
Impact of Reinsurance on Performance of Nepalese Insurance Companies

and negative relation with industry. Since, the result is not significant, reinsurance has no any key significant role in enabling to maintain the solvency margin of the primary insurer.

\section{Conclusion}

This article analyzes a sample of insurers from the Nepal and provides empirical evidence for the effect of reinsurance on profitability and solvency insurers. The result reveals that reinsurance has a positive and significant impact with profitability in life portfolio as measured by ROA while it was negatively related in nonlife and industry. In Regard to ROE, reinsurance has a positive but insignificant effect of reinsurance across all three portfolios. The result reveals that reinsurance has a positive impact on profitability of a primary insures. This means reinsurance improves the cost efficiency of insurers. In regard to solvency, the result deficit that positive but insignificant relation of reinsurance on solvency in both life and nonlife of the primary insurer while it was negatively related with the industry. The positive relation indicates reinsurance is a complement for capital in order to enhance solvency while negative relation indicating solvency of the insurers increases with the level of used reinsurance to the extent that reinsurance and capital can be substitutes of each other.

Thus, the study concludes that the sharing the risk with reinsurers, primary insurers can benefit from a relief on capital. Additional outcomes display an important relationship between demand and supply of reinsurance at the firm level, growing in the used reinsurance; primary insurers are more prone to providing reinsurance to other firms. In fact, the outcomes suggest that insurers' capital decreases in the amount of utilized reinsurance. Thus, a study concludes in line with the hypothesis that reinsurance can substitute capital for improving the solvency of insurers. In statistical terms, the impact of reinsurance is observed to be more important for solvency, than for profitability.

\section{Scope for future research}

This article could be further enhance exploring changes in the regulation related to reinsurance over time. Further, portfolio wise reinsurance practices and effect on performance also helps to identify the real effect. Analyzing the treaties of the insurer and execution of treaties in reality back up by data would also help to capture the real effect on firm performance are some of the areas to improve in future research.

Finally, the researcher like to encourage additional theoretical research in this field that should work to provide empirically more solid basis covering risk of reinsurance treaties. Also comparing the reinsurance practices across the countries would help more insightful findings which would be more helpful and create a strong foundation to the regulator to introduce new reinsurance regulation.

\section{Acknowledgment}

The author acknowledges comments and suggestion from Prof. Dr. Pushkhar Bajacharya and Prof. Dr. Fatta Bahadur K.C. Faculty of Tribuvan University. Researcher also like to give sincere thanks to respected chairman of Beema Samit Mr. Chiranivi Chapagin for always encouraging and supporting to carry out research of the insurance industry. 
Impact of Reinsurance on Performance of Nepalese Insurance Companies

\section{Funding Information}

This research paper has been prepared without any extern funding.

\section{Author's Contribution}

Mr. Rajendra Maharjan: Prepared the manuscript, revised, finalized and approved by himself.

\section{Conflict of Interest}

The author declares that there is no any conflict of interest

\section{References}

Altuntas, M., Garven, J., \& Rauch, J. (2018). On the corporate demand for insurance: evidence from the global reinsurance market. Risk Management and Insurance Review, 21(2), 211-242. https://doi.org/10.1111/ rmir.12107

Berger, L. A., Cummins, J. D., \& Tennyson, S. (1992). Reinsurance and the liability insurance crisis. Journal of Risk and Uncertainty, 5(3), 253-272. https://doi.org/10.1007/ BF00057882

Bressan, S. (2018). The impact of reinsurance for insurance companies. Risk Governance and Control: Financial Market \& Institution, 8(4), 22-20. http://doi.org/10.22495/ rgcv8i4p3

Choi, B. P. (2010). The US property and liability insurance industry: Firm growth, size, and age. Risk Management and Insurance Review, 13(2), 207-224. https://doi. org/10.1111/j.1540-6296.2010.01181.

Cole, C. R., \& McCullough, K. A. (2006). A reexamination of the corporate demand for reinsurance. Journal of Risk and Insurance, 73(1), 169-192. https://doi.org/10.1111/ j.1539-6975.2006.00170.x

De Haan, L., \& Kakes, J. (2010). Are non-risk based capital requirements for insurance companies binding?. Journal of Banking \& Finance, 34(7), 1618-1627. https://doi. org/10.1016/j.jbankfin.2010.03.008

Doherty, N. A., \& Tinic, S. M. (1981). Reinsurance under conditions of capital market equilibrium: A note. The Journal of Finance, 36(4), 949-953. https://doi. org/10.2307/2327559

Garven, J. R., \& Lamm-Tennant, J. (2002). Economic and financial perspectives on the demand for reinsurance. Rational Reinsurance Buying, 163-186.

Group of Thirty. (2006). Reinsurance and International Financial Markets. Group of Thirty.

Kuschel, N., Mamykina, E., \& Pavlis, R. (2011). Impact of reinsurance on risk capital - a practical example based on QIS5. Munich Re Solvency Consulting Knowledge Series, 1-11. 
Impact of Reinsurance on Performance of Nepalese Insurance Companies

Lee, H. H., \& Lee, C. Y. (2012). An analysis of reinsurance and firm performance: Evidence from the Taiwan property-liability insurance industry. The Geneva Papers on Risk and Insurance-Issues and Practice, 37(3), 467-484. https://doi.org/10.1057/gpp.2012.9

van Lelyveld, I., Liedorp, F., \& Kampman, M. (2011). An empirical assessment of reinsurance risk. Journal of Financial Stability, 7(4), 191-203.

Mankaï, S., \& Belgacem, A. (2016). Interactions between risk taking, capital, and reinsurance for property-liability insurance firms. Journal of Risk and Insurance, 83(4), 1007 1043. https://doi.org/10.1111/jori.12080

Nissim, D. (2010). Analysis and valuation of insurance companies. CE ASA (Center for Excellence in Accounting and Security Analysis) Industry Study, (2). https://papers. ssrn.com/sol3/ papers.cfm?abstract_id=1739204

Outreville, J. F. (2002). Introduction to insurance and reinsurance coverage. Social Reinsurance, 59.

Powell, L. S., \& Sommer, D. W. (2007). Internal versus external capital markets in the insurance industry: The role of reinsurance. Journal of Financial Services Research, 31(2-3), 173-188. https://doi.org/10.1007/s10693-007-0007-2

Surminski, S. (2018). Fit for purpose and fit for the future? An evaluation of the UK's new flood reinsurance pool. Risk Management and Insurance Review, 21(1), 33-72. https:// doi.org/ 10.1111/rmir.12093

Mashayekhi, M., \& Fernandes, D. (2007). Trade and development aspects of insurance services and regulatory frameworks. United Nations Publications. 